\title{
Association between polymorphisms of the $D B H$ and DAT1 genes and attention deficit hyperactivity disorder in children from Jordan
}

\author{
MOHAMMAD Y. GHARAIBEH ${ }^{1}$, SAJIDA BATAYNEH ${ }^{1}$, OMAR F. KHABOUR ${ }^{1}$ and AZHAR DAOUD $^{2}$ \\ Departments of ${ }^{1}$ Medical Laboratory Sciences, and ${ }^{2}$ Neuroloscience, \\ Jordan University of Science and Technology, Irbid 22110, Jordan
}

Received March 15, 2010; Accepted April 28, 2010

DOI: 10.3892/etm_00000108

\begin{abstract}
Attention deficit hyperactivity disorder (ADHD) is one of the most common neuropsychiatric disorders in children. In this study, the association between 10-repeats in the DATl gene and the (GT)n repeat in the $D B H$ gene and ADHD was examined in children from Jordan. In addition, the levels of dopamine- $\beta$-hydroxylase enzyme activity in the plasma of ADHD children were evaluated. Fifty children with ADHD and 50 age- and gender-matched control subjects were recruited. The results showed significant differences between the ADHD group and controls with respect to the plasma levels of dopamine- $\beta$-hydroxylase enzyme activity $(25.4 \pm 2.3$ vs. $84.7 \pm 5.0 \mu \mathrm{mol} / \mathrm{min}$; $<<0.01)$. Moreover, the 10 -repeat $D A T 1$ gene and (GT)n $D B H$ gene polymorphisms were significantly associated with ADHD development $(\mathrm{p}<0.05)$. In conclusion, the $D B H$ and $D A T 1$ genes appear to play a role in the development of ADHD in the Jordanian population.
\end{abstract}

\section{Introduction}

Attention deficit hyperactivity disorder (ADHD) is one of the most common neuropsychiatric and behavioral childhood disorders (1), affecting approximately $12 \%$ of school-aged children, with a higher prevalence in boys than girls (2). The disorder is characterized by reduced attention and hyperactivity (3-5); ADHD children are disorganized and have trouble fulfilling plans and completing tasks (6). The symptoms have been attributed, mainly, to lower norepinephrine and dopamine activities. Research has indicated a malfunction in dopamine- $\beta$-hydroxylase $(\mathrm{DBH})$, which is responsible for maintaining the balance between dopamine and norepinephrine concentrations (2,7-11).

Correspondence to: Dr Mohammad Y. Gharaibeh, Department of Medical Laboratory Sciences, Jordan University of Science and Technology, P.O. Box 3030, Irbid 22110, Jordan

E-mail: younisgh@just.edu.jo

Key words: attention deficit hyperactivity disorder, dopamine- $\beta$ hydroxylase, DAT1, norepinephrine
Recent data suggest that various polymorphisms of the dopamine-related genes are related to ADHD. Studies involving children from the US, Czech Republic, Finland, Brazil and India demonstrated a correlation between $D B H$ gene polymorphisms and increased susceptibility to ADHD (1,10-14). Moreover, studies from the US, Taiwan, UK and China revealed strong associations between ADHD and polymorphisms of the dopamine transporter gene (DAT1) $(12,15,16)$. Despite accumulating evidence, no studies have examined these relationships in Arab/Middle Eastern populations. Therefore, in this study the plasma levels of $\mathrm{DBH}$ enzyme activity were evaluated in ADHD children from Jordan. In addition, the association between polymorphisms of the DAT1 and $D B H$ genes and ADHD was examined.

\section{Materials and methods}

Subjects. Fifty children with ADHD (2.5-14 years of age) were recruited from the King Abdullah University Hospital and the Princess Rahmah Teaching Hospital. The children were diagnosed with ADHD according to the Diagnostic and Statistical Manual of Mental Disorder-IV (DSM-IV) criteria by a pediatric neurologist. Fifty healthy children, matched for age and gender, were included in the study as controls. The control children attended the same hospitals for reasons other than neuropsychiatric disorders. Written informed consent was obtained from the participants' guardians according to the Jordan University of Science and Technology Institutional Review Board.

DNA extraction. DNA was extracted from EDTA blood samples obtained from the participants using the Wizard DNA Extraction kit (Promega, Madison, WI, USA) according to the manufacturer's instructions. The concentration of the extracted DNA was measured using SmartSpect ${ }^{\mathrm{TM}} 3000$ (Bio-Rad, Hertfordshire, UK). DNA samples were stored at $-20^{\circ} \mathrm{C}$ until use.

Genotyping of the DAT1 polymorphism. The 40-bp variable number tandem repeat (VNTR) of the DAT1 3'-untranslated region was analyzed using polymerase chain reaction (PCR) as previously described (17). Detection of various repeats was 
Table I. Distribution of the genotypes of the DAT1 polymorphism.

\begin{tabular}{lrrrr}
\hline Genotype & Patients n (\%) & Control n $(\%)$ \\
\hline $6 / 6$ & 1 & $(2)$ & 0 & $(0)$ \\
$6 / 7$ & 2 & $(4)$ & 0 & $(0)$ \\
$7 / 7$ & 3 & $(6)$ & 3 & $(6)$ \\
$7 / 9$ & 2 & $(4)$ & 10 & $(20)$ \\
$7 / 10$ & 0 & $(0)$ & 2 & $(4)$ \\
$9 / 9$ & 7 & $(14)$ & 17 & $(34)$ \\
$9 / 10$ & 17 & $(34)$ & 14 & $(28)$ \\
$9 / 11$ & 1 & $(2)$ & 0 & $(0)$ \\
$10 / 10$ & 16 & $(32)$ & 4 & $(8)$ \\
$10 / 11$ & 1 & $(2)$ & 0 & $(0)$ \\
\hline
\end{tabular}

$\mathrm{p}<0.001$, based on the Fisher's exact test.

performed using $12 \%$ polyacrylamide gel and proper DNA ladders.

Genotyping of the DBH polymorphism. The $D B H$ dinucleotide repeat was performed using previously described primers and PCR conditions (18). The PCR products were digested with HaeIII at $37^{\circ} \mathrm{C}$ for $2 \mathrm{~h}$. The digested PCR products were analyzed using $12 \%$ polyacrylamide gels, and the sizes of the dinucleotide repeat were measured using proper DNA ladders (19).

Determination of dopamine- $\beta$-hydroxylase activity. The activity of the DBH enzyme was measured using the patch adsorption method according to the protocol used by Nagatsu and Udenfriend (20). In brief, $50 \mu \mathrm{l}$ of serum was added to $350 \mu \mathrm{l}$ of distilled water, and the diluted serum was added to $600 \mu \mathrm{l}$ of a reagent mixture [200 $\mu \mathrm{l}$ of sodium acetate buffer (1 mol/l, pH 5.0), $50 \mu \mathrm{l}$ of sodium fumarate $(0.2 \mathrm{~mol} / \mathrm{l}), 50 \mu \mathrm{l}$ of ascorbic acid $(0.2 \mathrm{~mol} / \mathrm{l}), 50 \mu \mathrm{l}$ of catalase $(1 \mathrm{mg} / \mathrm{ml}), 50 \mu \mathrm{l}$ of tyramine $(0.4 \mathrm{~mol} / \mathrm{l}), 50 \mu \mathrm{l}$ of pargyline $(20 \mathrm{mmol} / \mathrm{l})$ and $150 \mu \mathrm{l}$ of $\mathrm{N}$-ethylmalemide $(0.2 \mathrm{~mol} / \mathrm{l})]$. As a blank, $50 \mu \mathrm{l}$ of serum was diluted to $400 \mu \mathrm{l}$ by distilled water, boiled at $95^{\circ} \mathrm{C}$ for $5 \mathrm{~min}$ and then added to $600 \mu \mathrm{l}$ of the reagent mixture described above. The reaction mixtures were incubated at $37^{\circ} \mathrm{C}$ for $60 \mathrm{~min}$ with continuous shaking. At the end of the incubation period, the reactions were stopped by adding $200 \mu \mathrm{l}$ of trichloroacetic acid (3 molar), and the mixtures were centrifuged at $2,000 \mathrm{x} \mathrm{g}$ for $10 \mathrm{~min}$. The supernatant was transferred to a new tube containing $200 \mu \mathrm{l}$ of Dowex-50 $\left(\mathrm{H}^{+}, 200-400 \mathrm{mesh}\right)$, which was fully equilibrated with acetate buffer. The precipitants were then washed three times with distilled water coupled with centrifugation at 2,000 $\mathrm{x} g$ for 5 min each. After the last wash, $1 \mathrm{ml}$ of $\mathrm{NH}_{4} \mathrm{OH}$ (4 molar) was added to elute the adsorbed amines. The mixtures were then centrifuged at 2,000 x g for $5 \mathrm{~min}$, and the supernatants were transferred to new tubes. Following this, $100 \mu \mathrm{l}$ of $\mathrm{NaIO}_{4}$ (200 g/l) was added to the tube to convert the octopamine in the supernatant to para-hydroxybenzaldehyde. Finally, $100 \mu \mathrm{l}$ of $\mathrm{Na}_{2} \mathrm{~S}_{2} \mathrm{O}_{5}(10 \mathrm{~g} / \mathrm{l})$ was added to reduce the excess periodate. Absorbance was then measured at $330 \mathrm{~nm}$ using microcu-
Table II. Frequency of the DAT1 alleles.

\begin{tabular}{lcc}
\hline Alleles & Patients (n) & Controls (n) \\
\hline DAT6 & 4 & 0 \\
DAT7 & 10 & 18 \\
DAT9 & 34 & 58 \\
DAT10 & 50 & 24 \\
DAT11 & 2 & 0 \\
\hline
\end{tabular}

$\mathrm{p}<0.05$, based on the Fisher's exact test.

Table III. Distribution of the genotypes of the (GT)n DBH polymorphism in the studied population.

\begin{tabular}{lcc}
\hline Genotype & Patients n (\%) & Controls n $(\%)$ \\
\hline A2/A3 & $29(58)$ & $9(18)$ \\
A2/A4 & $1(2)$ & $28(56)$ \\
A3/A4 & $0(0)$ & $6(12)$ \\
A3/A6 & $0(0)$ & $1(2)$ \\
A4/A6 & $20(40)$ & $6(12)$ \\
\hline
\end{tabular}

$\mathrm{p}<0.05$, based on the Fisher's exact test.

Table VI. Allelic frequencies of the (GT)n DBH polymorphism in the studied population.

\begin{tabular}{lcc}
\hline Genotype & Patients (n) & Controls (n) \\
\hline A2 & 30 & 37 \\
A3 & 29 & 16 \\
A4 & 21 & 40 \\
A6 & 20 & 7 \\
\hline
\end{tabular}

$\mathrm{p}<0.001$

vets with a $1-\mathrm{cm}$ light path. The activity of the enzyme was expressed in terms of $\mu \mathrm{mol} / \mathrm{min}$; the level of DBH enzyme.

Statistical analysis. Statistical evaluation of the results was carried out by comparing allele, genotype and predicted phenotype distributions using the $\chi^{2}$ test. If $n<5$, the Fisher's exact test was used. The SPSS 15.0 statistical software package (SPSS Inc., Chicago, IL, USA) was used for all statistical evaluations. Comparisons that involved two groups were carried out using the Student's t-test. A p-value of $<0.05$ was considered significant.

\section{Results}

The sample ratio of boys to girls was 4:1. The median age was $7.1 \pm 1.2$ years for the ADHD subjects and $8 \pm 1.4$ for the control group $(\mathrm{p}>0.05)$. 
Table V. DBH enzyme activity in the blood levels of the study subjects.

\begin{tabular}{lccc}
\hline Dopamine- $\beta$-hydroxylase & Patients $(\mathrm{n}=50)$ & Controls $(\mathrm{n}=50)$ & P-value \\
\hline Activity (mean $\mu \mathrm{mol} / \mathrm{min})$ & $25.0 \pm 2.3$ & $84.6 \pm 5.0$ & $<0.01$ \\
Description of activity & & 43 & $<0.01$ \\
High $(>50 \mu \mathrm{mol} / \mathrm{min})$ & 4 & 7 & \\
Low $(<50 \mu \mathrm{mol} / \mathrm{min})$ & 46 & & \\
\hline
\end{tabular}

According to the distribution of the DATl polymorphism genotypes shown in Table I, 9/9 and 9/10 were most common in the controls (34 and 28\%, respectively). However, the most common genotypes in the ADHD group were 9/10 and 10/10 repeats (34 and 32\%, respectively). Additionally, Table II shows that the 9-repeat allele $(58 \%)$ was common in the controls, while the 10-repeat allele was common in the ADHD group $(50 \%, \mathrm{p}<0.05)$.

As shown in Table III, the frequency of (GT)n DBH polymorphism A2/A3 and A4/A6 genotypes was higher in the ADHD children (58 and 40\%, respectively), while the frequency of the A2/A4 genotype was higher in the controls $(56 \%, \mathrm{p}<0.05)$. In agreement with the genotype distribution, Table IV shows that the A3 and A6 allelic frequencies were higher in the ADHD group, while the frequency of the A4 allele was higher in the control group $(p<0.001)$.

The result also revealed a significant decrease $(\mathrm{p}<0.01)$ in the plasma DBH activity in the ADHD $(25.412 \pm 2.32 \mu \mathrm{mol} /$ min) compared to the control $(84.689 \pm 5.01 \mu \mathrm{mol} / \mathrm{min})$ children (Table V). Moreover, the percentage of children with abnormally low activity was higher $(\mathrm{p}<0.01$, Table $\mathrm{V})$ in the ADHD vs. the control group.

\section{Discussion}

The present study revealed that the frequency of the (GT)n repeat $5^{\prime}$ in the $D B H$ gene was higher in the ADHD group among Jordanian children. In addition, a significantly lower level of $D B H$ activity was detected in ADHD children compared to the controls.

Previous studies have revealed that an imbalance between the dopaminergic and noradrenergic systems is implicated in the development of ADHD in children $(10,16,21)$. The two systems are connected by the activity of the DBH enzyme, which is expressed in the central and peripheral nervous systems and catalyzes the conversion of dopamine to norepinephrine (22). Genetic variations in the $D B H$ gene suggest that a lower enzyme activity increases the susceptibility of developing ADHD in children. Several studies have shown an increased TaqI A polymorphism in children with ADHD $(12,14,23)$. In addition, several single-nucleotide polymorphisms in the $D B H$ gene have been implicated in ADHD etiology (21). Moreover, the $D B H(\mathrm{GT})$ n repeat polymorphism was found to contribute to the development of ADHD in children from the US (23). In the the present study, the $D B H$ (GT)n polymorphism was associated with ADHD children, supporting the hypothesis that $D B H$ plays a key role in the ADHD trait. Thus, similar to other populations, genetic varia- tions in the $D B H$ gene may play a role in the development of ADHD in Jordanian children.

Another gene that plays a key role in regulating the dopaminergic system is DAT1, which codes for a dopamine transporter expressed in pre-synaptic neurons (24). Previous studies have implicated excess dopamine clearance in the synapses of ADHD as part of the etiology of the disease (25). In addition, positron emission tomography imaging indicated dysregulation of DAT1 in the striatum of subjects with ADHD $(26,27)$. The present results indicate that VNTR in the 3' untranslated region of DAT1 is associated with ADHD with a high frequency of the $10 \mathrm{R}$ allele in affected children. In agreement with this result, several studies $(18,28)$ have found that homozygosity for the 10R allele of the DAT1 gene was significantly greater in ADHD children from the US, Ireland and Czech Republic $(12,29,30)$. In addition, a meta-analysis found a significant association between the 10R allele and ADHD development (31,32). Thus, similar to other populations, VNTR in the $3^{\prime}$ untranslated region of DAT1 may play a role in the etiology of ADHD in children from Jordan.

In support of the genetic analysis, DBH enzyme activity was significantly different in the ADHD group compared to the controls. The plasma DBH level can be used as a marker to reflect sympathetic noradrenergic activity, since the enzyme is released into the blood stream during synaptic transmission (33). Although plasma DBH enzyme activity varies among unrelated individuals (18), it is generally accepted that children with ADHD have decreased plasma and urine $\mathrm{DBH}$ activities $(10,19,34)$.

As is the case in most association studies, reported negative and positive associations with a given genetic variant are common. In the examined polymorphisms, lack of association between ADHD and the $D B H(\mathrm{GT})$ n repeat was reported in Indians (35). Similarly, the absence of an association between ADHD and VNTR of the DAT1 3'-untranslated region was observed in studies from Brazil and Norway (1,17,23,36-38). The discrepancy may be due to the complexity of ADHD, the differences in the genetic background of the studied populations, and the impact of environmental factors.

Previous studies have demonstrated that certain environmental factors, including maternal smoking or drinking habits during pregnancy, low birth weight, maternal age, stress and/or exposure to heavy metals such as zinc and mercury contribute to the development of ADHD $(6,39)$. However, the contribution of environmental factors to the development of ADHD in Jordanian children was not examined in the present study; it will be investigated in future research. 
Notably, DBH enzyme activity has been shown to change in individuals with certain diseases such as schizophrenia, Tourette syndrome, familial dysautonomia and orthostatic hypotension (40. Similarly, polymorphisms of DAT1 are associated with bipolar disorder, Parkinson disease and drug abuse $(41,42)$. Therefore, future studies should examine common variants of the $D B H$ and $D A T 1$ genes in Jordanians.

\section{Acknowledgements}

The authors thank Dr Abdulla Al-Sharman for the help in recruiting participants and Mr. Essa S. Abdelhalim for the help with statistical analysis. The study was funded by grant no. 53/2008 to M.G. and O.K. from the Deanship of Scientific Research of the Jordan University of Science and Technology.

\section{References}

1. Cheuk DK and Wong V: Attention-deficit hyperactivity disorder and blood mercury level: a case-control study in Chinese children. Neuropediatrics 37: 234-240, 2006.

2. Sheehan K, Hawi Z, Gill M and Kent L: No association between TPH2 gene polymorphisms and ADHD in a UK sample. Neurosci Lett 412: 105-107, 2007.

3. Gornick MC, Addington A, Shaw P, et al: Association of the dopamine receptor D4 (DRD4) gene 7-repeat allele with children with attention-deficit/hyperactivity disorder (ADHD): an update. Am J Med Genet B Neuropsychiatr Genet 144B: 379-382, 2007.

4. Thapar A, O'Donovan M and Owen MJ: The genetics of attention deficit hyperactivity disorder. Hum Mol Genet 14: R275-R282, 2005.

5. Tsai SJ: Attention-deficit hyperactivity disorder may be associated with decreased central brain-derived neurotrophic factor activity: clinical and therapeutic implications. Med Hypotheses 68: 896-899, 2007.

6. Rowland AS, Lesesne CA and Abramowitz AJ: The epidemiology of attention-deficit/hyperactivity disorder (ADHD): a public health view. Ment Retard Dev Disabil Res Rev 8: 162-170, 2002.

7. Gizer IR, Ficks C and Waldman ID: Candidate gene studies of ADHD: a meta-analytic review. Hum Genet 126: 51-90, 2009.

8. Guan L, Wang B, Chen Y, et al: A high-density single-nucleotide polymorphism screen of 23 candidate genes in attention deficit hyperactivity disorder: suggesting multiple susceptibility genes among Chinese Han population. Mol Psychiatry 14: 546-554, 2009.

9. Hesse S, Ballaschke O, Barthel H and Sabri O: Dopamine transporter imaging in adult patients with attention-deficit/ hyperactivity disorder. Psychiatry Res 171: 120-128, 2009.

10. Kopeckova M, Paclt I, Petrasek J, Pacltova D, Malikova M and Zagatova V: Some ADHD polymorphisms (in genes DAT1, DRD2, DRD3, DBH, 5-HTT) in case-control study of 100 subjects 6-10 age. Neuro Endocrinol Lett 29: 246-251, 2008.

11. Nyman ES, Ogdie MN, Loukola A, et al: ADHD candidate gene study in a population-based birth cohort: association with DBH and DRD2. J Am Acad Child Adolesc Psychiatry 46: 1614-1621, 2007.

12. Barkley RA, Smith KM, Fischer M and Navia B: An examination of the behavioral and neuropsychological correlates of three ADHD candidate gene polymorphisms (DRD4 7+, DBH TaqI A2, and DAT1 40 bp VNTR) in hyperactive and normal children followed to adulthood. Am J Med Genet B Neuropsychiatr Genet 141B: 487-498, 2006

13. Kopeckova M, Paclt I and Goetz P: Polymorphisms and low plasma activity of dopamine-beta-hydroxylase in ADHD children. Neuro Endocrinol Lett 27: 748-754, 2006.

14. Roman T, Schmitz M, Polanczyk GV, Eizirik M, Rohde LA and Hutz MH: Further evidence for the association between attention-deficit/hyperactivity disorder and the dopamine-betahydroxylase gene. Am J Med Genet 114: 154-158, 2002.

15. Brookes KJ, Mill J, Guindalini C, et al: A common haplotype of the dopamine transporter gene associated with attention-deficit/ hyperactivity disorder and interacting with maternal use of alcohol during pregnancy. Arch Gen Psychiatry 63: 74-81, 2006.
16. Krause J: SPECT and PET of the dopamine transporter in attention-deficit/hyperactivity disorder. Expert Rev Neurother 8: 611-625, 2008

17. Qian Q, Wang Y, Zhou R, Yang L and Faraone SV: Family-based and case-control association studies of DRD4 and DAT1 polymorphisms in Chinese attention deficit hyperactivity disorder patients suggest long repeats contribute to genetic risk for the disorder. Am J Med Genet B Neuropsychiatr Genet 128B: 84-89, 2004.

18. Wei J, Xu HM, Ramchand CN and Hemmings GP: Is the polymorphic microsatellite repeat of the dopamine beta-hydroxylase gene associated with biochemical variability of the catecholamine pathway in schizophrenia? Biol Psychiatry 41: 762-767, 1997.

19. Galvin M, Ten Eyck R, Shekhar A, et al: Serum dopamine beta hydroxylase and maltreatment in psychiatrically hospitalized boys. Child Abuse Negl 19: 821-832, 1995.

20. Nagatsu T and Udenfriend S: Photometric assay of dopamine hydroxylase activity in human blood. Clin Chem 18: 980-983, 1972.

21. Kopeckova M, Paclt I and Goetz P: Polymorphisms of dopaminebeta-hydroxylase in ADHD children. Folia Biol 52: 194-201, 2006.

22. Hartman BK: Immunofluorescence of dopamine-hydroxylase. Application of improved methodology to the localization of the peripheral and central noradrenergic nervous system. J Histochem Cytochem 21: 312-332, 1973.

23. Smith KM, Daly M, Fischer M, et al: Association of the dopamine beta hydroxylase gene with attention deficit hyperactivity disorder: genetic analysis of the Milwaukee longitudinal study. Am J Med Genet B Neuropsychiatr Genet 119B: 77-85, 2003.

24. Parsian A and Zhang ZH: Human dopamine transporter gene polymorphism (VNTR) and alcoholism. Am J Med Genet 74: 480-482, 1997.

25. Prince J: Catecholamine dysfunction in attention-deficit/ hyperactivity disorder: an update. J Clin Psychopharmacol 28: S39-S45, 2008

26. Jucaite A, Fernell E, Halldin C, Forssberg H and Farde L: Reduced midbrain dopamine transporter binding in male adolescents with attention-deficit/hyperactivity disorder: association between striatal dopamine markers and motor hyperactivity. Biol Psychiatry 57: 229-238, 2005.

27. Spencer TJ, Biederman J, Madras BK, et al: Further evidence of dopamine transporter dysregulation in ADHD: a controlled PET imaging study using altropane. Biol Psychiatry 62: 1059-1061, 2007.

28. Cook EH Jr, Stein MA, Krasowski MD, et al: Association of attention-deficit disorder and the dopamine transporter gene. Am J Hum Genet 56: 993-998, 1995.

29. Drtilkova I, Sery O, Theiner P, et al: Clinical and moleculargenetic markers of ADHD in children. Neuro Endocrinol Lett 29: 320-327, 2008.

30. Hawi Z, Segurado R, Conroy J, et al: Preferential transmission of paternal alleles at risk genes in attention-deficit/hyperactivity disorder. Am J Hum Genet 77: 958-965, 2005.

31. Faraone SV and Khan SA: Candidate gene studies of attentiondeficit/hyperactivity disorder. J Clin Psychiatry 67 (Suppl 8): 13-20, 2006.

32. Yang XM, Wang SH, Yang YD, et al: A dopaminergic projection from the dorsal raphe nucleus to the inner ear. Zhonghua Er Bi Yan Hou Tou Jing Wai Ke Za Zhi 41: 857-860, 2006.

33. O'Connor DT, Levine GL and Frigon RP: Homologous radioimmunoassay of human plasma dopamine-beta-hydroxylase: analysis of homospecific activity, circulating plasma pool and intergroup differences based on race, blood pressure and cardiac function. J Hypertens 1: 227-233, 1983.

34. Galvin MR, Stilwell BM, Shekhar A, Kopta SM and Goldfarb SM: Maltreatment, conscience functioning and dopamine beta hydroxylase in emotionally disturbed boys. Child Abuse Negl 21: 83-92, 1997.

35. Bhaduri N, Sarkar K, Sinha S, Chattopadhyay A and Mukhopadhyay K: Study on DBH genetic polymorphisms and plasma activity in attention deficit hyperactivity disorder patients from Eastern India. Cell Mol Neurobiol 30: 265-274, 2010.

36. Genro JP, Polanczyk GV, Zeni C, et al: A common haplotype at the dopamine transporter gene $5^{\prime}$ region is associated with attention-deficit/hyperactivity disorder. Am J Med Genet B Neuropsychiatr Genet 147B: 1568-1575, 2008.

37. Johansson S, Halleland H, Halmoy A, et al: Genetic analyses of dopamine related genes in adult ADHD patients suggest an association with the DRD5-microsatellite repeat, but not with DRD4 or SLC6A3 VNTRs. Am J Med Genet B Neuropsychiatr Genet 147B: 1470-1475, 2008. 
38. Langley K, Turic D, Peirce TR, et al: No support for association between the dopamine transporter (DAT1) gene and ADHD. Am J Med Genet B Neuropsychiatr Genet 139B: 7-10, 2005.

39. Swanson JM, Kinsbourne M, Nigg J, et al: Etiologic subtypes of attention-deficit/hyperactivity disorder: brain imaging, molecular genetic and environmental factors and the dopamine hypothesis. Neuropsychol Rev 17: 39-59, 2007.

40. Yoon DY, Rippel CA, Kobets AJ, et al: Dopaminergic polymorphisms in Tourette syndrome: association with the DAT gene (SLC6A3). Am J Med Genet B Neuropsychiatr Genet 144B: 605-610, 2007.
41. Bannon MJ: The dopamine transporter: role in neurotoxicity and human disease. Toxicol Appl Pharmacol 204: 355-360, 2005.

42. Kurian MA, Zhen J, Cheng SY, et al: Homozygous loss-of-function mutations in the gene encoding the dopamine transporter are associated with infantile parkinsonism-dystonia. J Clin Invest 119: 1595-1603, 2009. 